\title{
HUBUNGAN EKARISTI DENGAN HIDUP SEHARI-HARI DALAM TEOLOGI SAKRAMENTAL KARL RAHNER
}

\author{
E. Pranawa Dhatu Martasudjita*
}

\begin{abstract}
Abstrak: Diskusi mengenai hubungan Ekaristi dengan hidup seharihari masih terus berlangsung hingga hari ini, baik di kalangan para teolog maupun umat beriman pada umumnya. Kiasan yang sering digunakan di Indonesia untuk melukiskan hubungan tersebut adalah altar dan pasar. Yang menjadi bahan diskusi ialah masih adanya pandangan dikotomis yang memisahkan keduanya. Tulisan ini ingin memberi sumbangan kepada diskusi tentang tema tersebut dari pemikiran teologis Karl Rahner (1904-1984). Rahner menunjukkan bahwa pemahaman tentang rahmat sebagai pemberian diri Allah yang senantiasa diberikan dan dianugerahkan kepada umat manusia dan sejarahnya tidak memperkenankan pemisahan dikotomis semacam itu. Penulis mendekati permasalahan tersebut dengan pertama-tama menggali pemikiran sakramental Rahner, kemudian memperdalamnya dalam teologi Ekaristi. Dari alur pemikiran ini dibahas teologi Rahner yang senantiasa berciri pastoral, yaitu menghubungkan makna Ekaristi dengan kehidupan seharihari. Bagi Rahner, Ekaristi adalah sakramen sehari-hari. Dalam pengertian ini, kehidupan sehari-hari orang Kristiani mestinya merupakan perpanjangan dari hidup sehari-hari Kristus sendiri yang dirayakan dan diterima dalam Ekaristi.
\end{abstract}

Kata-kata Kunci: Ekaristi, hidup sehari-hari, teologi sakramental, altar dan pasar, sakramen sehari-hari.

Abstract: Theologians, as well as Christians in general continue discussing more deeply correlation between Eucharistic celebration and one's daily life. Yet, many are still employing a dichotomous approach between altar and marketplace. This article is intended to contribute to the discussion, especially by presenting important theological insights

* E. Pranawa Dhatu Martasudjita, Fakultas Teologi, Universitas Sanata Dharma, Jl. Kaliurang Km 7, Yogyakarta 55011. E-mail:martasudjita@yahoo.com. 
of Karl Rahner (1904-1984) who would not allow such a dichotomy. Rahner presents a creative theology of grace primarily as God's Self-gift, continuously offered to every single human being throughout our history. We will begin with the presentation of Rahner's sacramental theology, followed by the theology of the Eucharist. Rahner's theological thought, it is argued, remains pastoral in character, that relates meaning of the Eucharist to day-to-day Christian living and practices. For Rahner, the Eucharist is a sacrament of the everyday. In this sense, the Christian's daily life should be the extension of the daily life of Christ celebrated and received in the Eucharist.

Keywords: Eucharist, daily life, sacramental theology, altar and marketplace, sacrament of the everyday.

\section{PENDAHULUAN}

Hubungan antara Ekaristi dengan kehidupan sehari-hari senantiasa menjadi bahan pembicaraan teologis yang tidak ada habis-habisnya, khususnya di bidang teologi sakramen dan liturgi. Kita sebut saja pembahasan tema tersebut pada dekade terakhir yang lalu. Dekade tahun 2000-an ditandai oleh rangkaian ajaran dan refleksi teologis yang mendalam mengenai Ekaristi. Salah satu ajaran Gereja terpenting mengenai Ekaristi pada dekade tersebut ialah ensiklik Ecclesia de Eucharistia dari Paus Yohanes Paulus II pada 2003, yang menandai dua puluh lima tahun masa pontifikatnya. ${ }^{1}$ Secara eksplisit, Paus Yohanes Paulus II menghubungkan Ekaristi dengan kehidupan sehari-hari, saat ia membicarakan dimensi eskatologis dari Ekaristi. ${ }^{2}$ Setahun setelah menulis ensiklik tentang

1 Paus Yohanes Paulus II menulis: “Sejak awal pelayanan saya sebagai Pengganti Petrus, selalulah saya menandai hari Kamis Putih sebagai hari Ekaristi dan imamat. Saya menulis surat kepada semua imam di seluruh dunia. Tahun ini, dua puluh lima tahun Pontifikat saya, saya ingin melibatkan seluruh Gereja secara lebih penuh dalam permenungan Ekaristi, juga sebagai ungkapan syukur kepada Tuhan yang mengaruniakan Ekaristi dan imamat: 'Karunia dan Misteri'." John Paul II, Encyclical Letter "Ecclesia de Eucharistia: On the Eucharist in Its Relationship to the Church" (Vatican City: Libreria Editrice Vaticana, 2003), art. 7. Untuk selanjutnya disebut Ecclesia de Eucharistia diikuti dengan nomor artikel.

2 "Konsekuensi penting dari tegangan eskatologis sebagaimana terdapat dalam Ekaristi adalah juga kenyataan panduannya terhadap peziarahan kita sepanjang 
Ekaristi itu, Paus Yohanes Paulus II menjadikan tahun 2004-2005 sebagai Tahun Ekaristi melalui surat apostolik, Mane Nobiscum Domine. Dari sekian alasan mengenai diundangkannya Tahun Ekaristi pada waktu itu, Yohanes Paulus II menyebut pentingnya Gereja memberikan kesaksian kepada dunia yang telah diwarnai sekularisasi ini akan kehadiran Allah yang bersifat tetap dan istimewa melalui Ekaristi dalam hidup seharihari. ${ }^{3}$ Tahun Ekaristi tersebut dibuka dengan Kongres Ekaristi Internasional di Guadalajara, Meksiko, pada Oktober 2004 dan ditutup dengan Sinode Para Uskup di Roma pada Oktober 2005.

Tema yang diangkat dalam Sinode Para Uskup tersebut ialah “Ekaristi sebagai sumber dan puncak hidup dan perutusan Gereja." Tema ini jelas sekali membahas kaitan Ekaristi dan kehidupan serta perutusan Gereja di tengah dunia, kancah hidup sehari-hari umat beriman. Hasil sinode ini menjadi pangkal tolak surat apostolik Paus Benediktus XVI, Sacramentum Caritatis, yang diterbitkan pada 2007. Sebagaimana dirumuskan sendiri oleh Paus Benediktus XVI, tujuan dari surat apostlik itu adalah untuk memberikan arahan mendasar bagi pembaruan komitmen dalam mengembangkan antusiasme dan gairah Ekaristi dalam Gereja, termasuk perutusan Gereja di tengah perjuangan kehidupan sehari-hari dalam dunia. ${ }^{4}$

Pada 2009 Federasi Konferensi-konferensi Waligereja Asia (FABC) mengadakan Sidang Pleno kesembilan di Manila dengan mengambil tema "Menghidupi Ekaristi di Asia (Living the Eucharist in Asia)." Dalam sidang tersebut FABC menghubungkan dengan bagus dan indah dialog kehidupan dan kasih Tuhan sebagaimana dirayakan dalam Ekaristi. ${ }^{5}$

sejarah, dan serentak menyemaikan benih pengharapan yang hidup dalam komitmen harian kita untuk melakukan pekerjaan kita." Ecclesia de Eucharistia, art. 20.

3 John Paul II, Apostolic Letter Mane Nobiscum Domine for the Year of the Eucharist October 2004-October 2005 (Vatican City: Libreria Editrice Vaticana, 2004), art. 26. Untuk selanjutnya disebut Mane Nobiscum Domine diikuti dengan nomor artikel.

4 Benediktus XVI, Sacramentum Caritatis: Anjuran Apostolik Pasca-Sinode, 22 Februari 2007. Terjemahan oleh Ernest Mariyanto (Jakarta: Komisi Liturgi KWI, 2007), art. 5. Untuk selanjutnya disebut Sacramentum Caritatis diikuti dengan nomor artikel.

5 Hasil Sidang Pleno IX FABC di Manila dapat dilihat dalam FABC Papers No. 129, Living the Eucharist in Asia - IX FABC Plenary Assembly 10-16 August, 2009 in Pope Pius XII Catholic Center, Manila, Philippines (Hongkong: FABC, 2010). 
Di Indonesia sendiri, pembahasan tema Ekaristi dan hidup seharihari sering dirumuskan secara metaforis melalui hubungan antara altar dan pasar. ${ }^{6}$ Altar menunjuk pada Ekaristi dan pasar menunjuk pada kehidupan konkret sehari-hari dalam masyarakat. Pada umumnya orang memahami bahwa Ekaristi dan hidup sehari-hari sebagai satu kesatuan, sebagaimana altar dan pasar juga tidak pernah boleh dipisah- kan. Masalahnya, bagaimana kesatuan yang tak terpisahkan antara Ekaristi dan hidup sehari-hari itu mesti dipikirkan dan dipahami. Inilah problematika yang menjadi latar belakang tulisan ini.

Tulisan ini ingin membahas hubungan Ekaristi dengan praksis hidup sehari-hari dalam teologi Karl Rahner. Dalam tulisan ini penulis menyajikan hasil penelitian dan penggalian pandangan teologis Rahner mengenai hubungan Ekaristi dengan praksis hidup sehari-hari. Meskipun Rahner telah wafat hampir tiga puluh tahun yang lalu, namun pandangannya tetap relevan dan memberikan inspirasi dalam pembahasan tentang problematika hubungan Ekaristi dengan praksis tersebut. Rahner sendiri sebenarnya telah menulis sebuah artikel dengan tema yang sama: "The Eucharist and Our Daily Lives."7 Tentu saja pembahasan penulis bukanlah sebuah "article report" atau sekedar laporan dari hasil pembacaan atas artikel Rahner tersebut, melainkan sebuah usaha untuk menggali pemikiran Rahner tentang tema tersebut dalam konteks keseluruhan teologi sakramentalnya dan mencari relevansinya bagi kehidupan iman di Indonesia. Dengan demikian secara keseluruhan penulis menggali pandangan teologi Rahner dengan bertolak dari pandangan teologi sakramennya, secara khusus teologi Ekaristinya, dan bagaimana

6 Ada banyak tulisan di majalah dan tulisan populer yang mengulas hubungan Ekaristi dan hidup sehari-hari dengan kiasan: altar dan pasar. Umumnya orang memandang bahwa peristilahan hubungan altar dan pasar ini dimunculkan pertama kali oleh Mgr. Alexander Djajasiswaja, Uskup Bandung (1931-2006). Salah satu tulisan mengenai hubungan liturgi dan hidup sehari-hari melalui gambaran metaforis altar dan pasar, dapat dilihat dalam Boli Ujan, SVD, “Kolekte sebagai Kegiatan Liturgis: Bawa Pasar ke Altar dan Altar ke Pasar?" http://katolisitas.org/4632/kolekte-sebagai-kegiatanliturgis-bawa-pasar-ke-altar-dan-altar-ke-pasar. Diunduh tanggal 11 Agustus 2013.

7 Karl Rahner, “The Eucharist and Our Daily Lives" in Karl Rahner, Theological Investigations, Volume (London: Darton, Longman \& Todd, 1971), pp. 211-226. 
Rahner memikirkan relasi Ekaristi dengan praksis hidup sehari-hari. Dari sini penulis menarik beberapa poin relevansinya bagi problematika hubungan Ekaristi dan hidup sehari-hari dalam konteks Indonesia.

\section{TEOLOGI SAKRAMENTAL RAHNER ${ }^{8}$}

Untuk menjelaskan paham tentang sakramen-sakramen, Rahner memunculkan istilah perubahan kopernikan. ${ }^{9}$ Dengan istilah perubahan kopernikan, Rahner memaksudkan suatu perubahan cara pikir dalam pemahaman sakramen, dari cara klasik ke cara baru. Dalam cara klasik, orang-orang Kristen menerima rahmat dari Allah yang disalurkan melalui perayaan sakramen-sakramen. Dalam hal ini rahmat sakramen seolah-olah masuk dan diterima oleh penerima sakramen dari luar, yaitu dari Allah sendiri pada saat penerimaan sakramen itu. Sedangkan cara baru yang ditawarkan oleh Rahner justru melihat rahmat sakramen itu sebagai diri Allah sendiri yang sebenarnya sudah ada dan telah diberikan oleh Allah kepada manusia, dan bahkan melekat pada eksistensi manusia sendiri. Dengan demikian poin dan kunci pemahaman baru yang ditawarkan Rahner ialah bagaimana memahami sakramen berpangkal dari makna rahmat itu sendiri.

Paham tentang rahmat dapat dianggap sebagai gagasan sentral dalam teologi Rahner. ${ }^{10}$ Rahner selalu memahami konsepsi rahmat dalam rangka sejarah keselamatan. Dengan demikian pemahaman Rahner mengenai teologi sakramen juga ditempatkan dalam konteks sejarah

8 Gagasan tentang teologi sakramental Rahner secara agak rinci pernah penulis sampaikan dalam artikel "Pemikiran Sakramental Karl Rahner dan Aktualisasinya," Melintas 20 (Desember 2004-Maret 2005): 75-93. Beberapa gagasan dalam artikel terdahulu muncul di sini.

9 Karl Rahner, "Über die Sakramente der Kirche," in Schriften zur Theologie XV herausgegeben von Karl Rahner (Zürich-Einsiedeln-Köln: Benziger, 1983), S. 11.

10 Hal ini tampak misalnya dari tulisan Rahner sendiri, "Selbstmitteilung Gottes," in Herders Theologisches Taschenlexikon, Band 7, herausgegeben von Karl Rahner (Freiburg: Herder, 1972-1973), S. 627; atau Grundkurs des Glaubens: Einführung in den Begriff des Christentums (Freiburg: Herder, 1991), SS. 122-142. Sentralitas konsepsi rahmat dalam teologi Rahner ini disebut, misalnya, dalam Josef Meyer zu Schlochtern, Sakrament Kirche: Wirken Gottes im Handel der Menschen (Freiburg: Herder, 1992), S. 194; Medard Kehl, Kirche als Intitution (Frankfurt a.M.: Josef Knech, 1976), SS. 196-198. 
keselamatan Allah. ${ }^{11}$ Sejarah keselamatan Allah dipahami Rahner sebagai pelaksanaan pemberian diri Allah (Selbstmitteilung Gottes) dalam rangka sejarah, yang meliputi seluruh sejarah dunia maupun manusia. Konsepsi pemberian diri Allah (Selbstmitteilung Gottes) ini merupakan gagasan sentral dalam teologi Rahner, bahkan Rahner sendiri menyebutkan bahwa istilah pemberian diri Allah itu merupakan konsepsi kunci dalam teologinya. ${ }^{12}$ Bagi Rahner, Allah tidak hanya mengomunikasikan sabda dan kehendak-Nya kepada manusia, tetapi Allah juga memberikan diri-Nya sendiri kepada manusia. Allah bukan hanya sebagai Sang Pemberi, tetapi juga Yang Diberikan. ${ }^{13}$ Paham mengenai pemberian diri Allah ini dikembangkan Rahner terutama untuk menjelaskan pandangannya tentang rahmat. Dalam teologi klasik, seperti dalam teologi neo-skolastik, rahmat lebih dipahami sebagai "sesuatu," entah itu sebagai suatu bantuan atau pertolongan dari Allah. Orang memperoleh rahmat berarti bahwa orang itu menerima bantuan dari surga, entah itu suatu penerangan atau suatu intervensi ilahi yang kudus dari surga. Dalam pandangan klasik ini, rahmat merupakan sesuatu yang dapat terjadi di suatu tempat dan dialami oleh seseorang dalam peristiwa yang khusus atau tertentu, seperti halnya orang di Jawa menyebutnya "wangsit." 14

Menurut Rahner, rahmat pertama-tama adalah diri Allah sendiri yang dianugerahkan kepada kita. Rahmat adalah pemberian diri Allah. Berbeda dari pandangan klasik yang memandang rahmat sebagai semacam intervensi ilahi yang turun pada seseorang secara khusus, di tempat tertentu dan melalui pengalaman istimewa, Rahner memahami rahmat sebagai pemberian diri Allah yang ada di mana-mana dan menopang seluruh eksistensi manusia, sehingga manusia memiliki keterbukaan kepada Allah. Rahner mengatakan: "Rahmat adalah keterbukaan yang

11 Karl Lehmann dalam pengantar buku Karl Rahner yang berjudul Über die Sakramente der Kirche: Meditationen (Freiburg: Herder, 1991), S. 8.

12 Karl Rahner, "Selbsmitteilung Gottes," S. 37.

13 Karl Rahner, "Über die Eigenart des christlichen Gottesbegriffs," in Schriften zur Theologie XV (Zürich: Benziger, 1983), S. 190.

14 Orang Jawa memahami rahmat menurut pemahaman tentang wahyu sebagai wangsit, yaitu sesuatu yang turun dari atas dan masuk ke dalam diri seseorang. 
bersifat mendasar dan mencakup seluruh kesadaran manusiawi terhadap kehadiran Allah, yakni suatu keterbukaan yang ditopang oleh pemberian diri Allah." ${ }^{15}$ Pemberian diri Allah ini bukanlah semacam tawaran yang seolah-olah dapat ditolak atau diterima secara bebas. Pemberian diri Allah ini melekat secara intrinsik dalam eksistensi manusia dan menopang seluruh sejarah dunia. Dalam arti inilah Rahner memahami sejarah keselamatan Allah sebagai pelaksanaan pemberian diri Allah yang berlangsung sepanjang sejarah. Dalam sejarah keselamatan Allah tersebut, Allah sendiri yang menjadi tujuan dari seluruh pemberian diri-Nya. Pemberian diri Allah-yang terdapat dan ada di manamana dalam seluruh sejarah dunia-itu menggerakkan seluruh pusat dunia kepada Allah. Itulah yang disebut rahmat. Apabila manusia dengan segala kebebasannya menolak pemberian diri Allah itu, pemberian diri Allah tetap ada dan menopang seluruh eksistensi dunia dan eksistensi manusia.

Pemberian diri Allah yang ada serta menopang seluruh dunia dan umat manusia inilah yang menjadi isi dari sejarah keselamatan umum atau universal. Allah memberikan diri-Nya kepada seluruh umat manusia sepanjang sejarah. Di sini sejarah keselamatan Allah koekstensif dengan seluruh sejarah dunia. ${ }^{16}$ Tetapi pemberian diri Allah dalam seluruh sejarah dunia dan manusia itu masih bersifat implisit dan belum menemukan tanggapannya yang terungkap. Dalam arti inilah Rahner menyebut adanya sejarah keselamatan khusus sebagaimana dipersiapkan dalam Perjanjian Lama dan berpuncak pada Yesus Kristus, yang ia rumuskan sebagai "menjadi terungkapnya atau dapat ditangkapnya secara historis sejarah keselamatan Allah, yang terentang dalam keseluruhan sejarah, yakni sejarah keselamatan yang berupa pemberian diri Allah yang mengilahikan hakikat manusia dalam seluruh dimensinya." ${ }^{17}$ Puncak pemberian diri Allah kepada manusia dan sekaligus puncak tanggapan manusia terhadap pemberian diri Allah itu terjadi pada diri

15 Karl Rahner, Über die Sakramente der Kirche, S. 13.

16 Karl Rahner, Grundkurs des Glaubens, S. 147.

17 Karl Rahner, Grundkurs des Glaubens, S. 397. 
Yesus Kristus. Dalam diri Yesus Kristus dengan seluruh kemanusiaanNya seluruh diri Allah dinyatakan dan dihadirkan sepenuhnya. Dengan lain kata, Yesus Kristus itu sekaligus ilahi dan manusiawi. Ia ilahi karena menyatakan pemberian diri Allah dan manusiawi karena Ia hidup secara historis sebagai manusia. Dalam arti inilah Yesus Kristus oleh Rahner disebut sebagai sakramen induk (Ursakrament).

Yesus Kristus-yang menjadi sakramen induk karena menandakan dan sekaligus menghadirkan diri Allah yang memberikan diri itu-kini tetap hadir di tengah dunia melalui dan di dalam Gereja. Karenanya, Rahner menyebut Gereja sebagai sakramen dasar (Grundsakrament)..$^{18}$ Sebagai sakramen dasar, Gereja menjadi simbol real dari kehadiran Kristus dan seluruh karya penyelamatan-Nya yang menghadirkan dan melaksanakan pemberian diri Allah bagi dunia dalam sepanjang perjalanan sejarah dunia ini hingga akhir zaman nanti. Dalam perspektif sejarah keselamatan, Gereja menghadirkan secara kelihatan tindakan penyelamatan Allah bagi dunia yang terlaksana dan mencapai puncaknya dalam diri Yesus Kristus. ${ }^{19}$ Gereja menjadi sakramen dasar karena kesatuannya dengan Kristus. Kesatuannya dengan Kristus menjadikan Gereja sebagai kehadiran kesanggupan Allah untuk menyelamatkan dunia dalam sejarahnya. ${ }^{20}$

Bagaimana Gereja melaksanakan dirinya sebagai sakramen Yesus Kristus secara konkret kepada masing-masing pribadi manusia? Bagaimanakah pemberian diri Allah yang terpadatkan dalam diri Kristus yang peristiwanya berpuncak pada misteri wafat dan kebangkitan-Nya itu ditandakan dan dihadirkan oleh Gereja bagi dunia dan manusia? Di sinilah arti dan tempat sakramen-sakramen atau ketujuh sakramen dipahami oleh Rahner. Rahner sendiri merumuskan:

18 Karl Rahner, Über die Sakramente der Kirche, S. 19.

19 Bdk. Karl Rahner, Kirche und Sakrament, S. 17.

20 Bdk. Josef Meyer zu Schlochtern, Sakrament Kirche: Wirken Gottes im Handeln der Menschen (Freiburg: Herder, 1992), S. 218. 
Di mana janji diri Allah yang memberikan diri-Nya (sebagai keselamatan) dan yang telah terlaksana secara final dan pasti (dalam Kristus) menjadi tampak kelihatan-historis dalam kehidupan setiap orang secara konkret, sebagaimana itu disampaikan melalui Gereja sebagai sakramen dasar, maka kita sedang berbicara mengenai sakramen-sakramen Kristiani. ${ }^{21}$

Secara sederhana dapat dikatakan bahwa Rahner memahami ketujuh sakramen sebagai konkretisasi secara kelihatan dan historis pemberian diri Allah yang berpuncak pada diri Yesus Kristus melalui Gereja bagi dunia menurut konteks situasi dan kondisi manusia. Melalui sakramen-sakramen itu Gereja mengungkapkan dan melaksanakan dirinya sebagai sakramen Yesus Kristus menurut konteks situasi konkret masingmasing orang. Berkaitan dengan ketujuh sakramen ini, Rahner menyebut dua segi. ${ }^{22}$ Pertama, sakramen-sakramen merupakan simbol real yang menandakan secara nyata pemberian diri Allah melalui Kristus sebagaimana ditampakkan dalam Gereja. Kedua, sakramen-sakramen itu berdaya guna, artinya menghadirkan rahmat, yakni pemberian diri Allah itu sendiri. Orang yang menerima sakramen-sakramen bukan hanya menangkap tanda kehadiran pemberian diri Allah itu tetapi juga mengalami dan menerima pemberian diri Allah yang selalu terjadi melalui Yesus Kristus dalam Roh Kudus dan berlangsung di dalam Gereja-Nya.

\section{EKARISTI SEBAGAI SAKRAMEN PEMBERIAN DIRI ALLAH MELALUI KRISTUS}

Rahner melihat Ekaristi bukan sekedar sebagai salah satu dari ketujuh sakramen Gereja, tetapi sebagai sakramen yang paling istimewa. Rahner merumuskan Ekaristi sebagai sakramen Gereja dalam pengertian yang paling padat atau menentukan; maksudnya, “justru karena penetapan Ekaristi dalam perjamuan malam terakhir memiliki makna yang menentukan bagi penetapan atau pendirian Gereja dan bagi pemahaman diri Yesus sebagai Penyelamat." ${ }^{23}$ Rahner menggali makna dan kekhasan

21 Karl Rahner, Grundkurs des Glaubens, S. 397.

22 Karl Rahner, Über die Sakramente der Kirche, SS. 20-21; lihat tulisan kami "Pemikiran Sakramental Karl Rahner dan Aktualisasinya," hlm. 86-87.

23 Karl Rahner, Grundkurs des Glaubens, S. 408. 
Ekaristi berdasarkan data Kitab Suci, khususnya teks Luk. 22:14-23 dan 1Kor. 11:23-26. ${ }^{24}$ Dalam perjamuan malam terakhir, Yesus menggunakan simbolisasi roti dan anggur yang disebut-Nya tubuh dan darahNya sebagai santapan para murid-Nya. Dari kata-kata yang diucapkanNya atas roti dan anggur saat dibagikan kepada para murid-Nya (katakata institusi), Yesus jelas memaksudkan penyerahan atau pemberian diri-Nya secara tuntas dan paling radikal yaitu dalam kematian-Nya. Yesus menyadari nasib-Nya yang akan berakhir di salib dan hal itu tidak terpisahkan dari karya pewartaan-Nya tentang Kerajaan Allah. Dari sini Rahner menyatakan bahwa Yesus memahami perjamuan tersebut secara eskatologis yaitu sebagai antisipasi ke dalam sukacita pesta abadi di surga. Sebagai perjamuan, makna kebersamaan dari Ekaristi menjadi penting yakni sebagai ikatan kesatuan Yesus dengan para sahabat-Nya dan pendirian jemaat (Gereja) dari para sahabat-Nya.

Dalam tulisannya mengenai teologi Ekaristi Rahner, William V. Dych melihat teologi tersebut dari sudut kristologi, terutama misteri Paskah yaitu misteri wafat dan kebangkitan Kristus..$^{25}$ Menurut Dych, gagasan pokok Rahner mengenai Ekaristi berpusat pada misteri Paskah. ${ }^{26}$ Pandangan Dych ini tepat, karena Rahner memang menempatkan diri dalam pemahaman dan ajaran Gereja mengenai Ekaristi sebagai perayaan misteri Paskah, seperti diungkapkan oleh Konsili Vatikan II: "Gereja tidak pernah lalai mengadakan pertemuan untuk merayakan misteri Paskah; di situ mereka membaca 'apa yang tercantum tentang Dia dalam seluruh Kitab Suci (Luk. 24:27); mereka merayakan Ekaristi yang menghadirkan kemenangan dan kejayaan-Nya atas maut'." 27 Tetapi Dych tidak membahas lebih dalam mengenai teologi Misteri Paskah, yang dari sisi sejarah teologi merupakan sumbangan besar dari teologi misteri Odo Casel pada dekade ketiga hingga kelima abad XX.

24 Karl Rahner, Grundkurs des Glaubens, SS. 408-409.

25 William V. Dych, "Karl Rahner's Theology of Eucharist," Philosophy \& Theology 11/1 (1998): 125-146.

26 William V. Dych, "Karl Rahner's Theology of Eucharist," Philosophy \& Theology 11/1 (1998): 127-133.

27 Sacrosanctum Concilium, art. 6. 
Studi atas tulisan Rahner, Grundkurs des Glaubens, ataupun tulisannya yang lain menunjukkan bahwa meski tetap menyebut sentralitas wafat dan kebangkitan Kristus dalam teologi Ekaristinya, Rahner juga memberi tekanan khusus mengenai makna kurban dan perjamuan yang tidak boleh dipisahkan. Tentang makna kurban dan perjamuan ini, Dych kurang menyinggung dan membahasnya, padahal menurut penulis, tema tersebut penting bagi Rahner. Rahner menyatakan bahwa dalam perayaan Ekaristi sungguh hadir kurban berdarah Yesus Kristus di salib melalui tindakan kurban liturgis Gereja yang dilaksanakan atas kehendak Kristus sendiri. ${ }^{28}$ Yesus Kristus sendiri yang menghendaki dan menetapkan Ekaristi agar para murid-Nya mengenangkan Dia dan persahabatan dengan-Nya, melalui perintah: "Perbuatlah ini menjadi peringatan akan Aku" (Luk. 22:19; 1Kor. 11:24). Tubuh dan darah Kristus yang hadir dalam rupa roti dan anggur itu benar-benar tubuh Kristus dalam pengertian seluruh pribadi Yesus Kristus yang dapat diraih secara lahiriah-badaniah, dan darah Kristus dalam pengertian seluruh diri Yesus Kristus yang menjadi perjanjian bagi umat manusia (Yes. 42:6). Rahner juga menekankan makna pengurbanan diri-Nya sebagai Hamba Tuhan yang bersengsara demi keselamatan sesama (bdk. Yes. 53:4-12). Perayaan Ekaristi adalah sungguhsungguh perjamuan, sejauh dalam perjamuan itu dihidangkan tubuh dan darah Yesus Kristus sebagai santapan, dan sekaligus sungguh-sungguh kurban, sejauh yang dikurbankan Gereja dalam Ekaristi itu hanyalah satusatunya kurban salib Kristus. ${ }^{29}$ Bagi Rahner, Ekaristi sebagai perayaan perjamuan dan kurban merupakan satu kesatuan pemahaman teologis, sebagaimana juga misteri inkarnasi, wafat dan kebangkitan, serta peninggian Kristus.

Ketika merefleksikan Ekaristi, Rahner tetap konsisten dengan pemikirannya tentang rahmat sebagai pemberian diri Allah. Isi atau daya guna sakramen Ekaristi tidak lain adalah pemberian diri Allah sendiri sebagaimana mengalami puncaknya dalam diri Yesus Kristus dan kini dihadirkan bagi dunia melalui Gereja yang melaksanakan dirinya dalam sakra-

28 Karl Rahner, Grundkurs des Glaubens, S. 409.

29 Karl Rahner, Grundkurs des Glaubens, SS. 409-410. 
mensakramen. Dalam perayaan Ekaristi pemberian diri Allah itu terjadi paling intensif atau paling padat, sebab "pemberian diri Allah itu 'dirumuskan atau dinyatakan' oleh hidup Yesus yang selalu dikasihi dan diterima secara final dalam tubuh dan darah." ${ }^{\prime 30}$ Pemberian diri Allah yang menjadi isi atau rahmat Ekaristi ini bukan hanya diterima secara pribadi oleh umat beriman tetapi juga bermakna sosial-eklesiologis. Dalam Ekaristi kehendak penyelamatan Allah yang berbelas kasih kepada seluruh umat manusia di dunia ini menjadi hadir, dapat diraih, dan kelihatan. Hal itu dimungkinkan sejauh paguyuban umat beriman yang kelihatan menjadi tanda bagi kehadiran rahmat dan kehendak penyelamatan Allah sebagai pemberian diri Allah yang sebenarnya hadir di mana-mana. Ekaristi menjadi sakramen kehadiran Tuhan yang paling radikal dan paling real dalam bentuk perjamuan sejauh perayaan ini menjadi pelaksanaan hakikat diri Gereja. Pemberian diri Allah yang ada dalam seluruh sejarah keselamatan dan yang mengalami puncaknya melalui diri Yesus Kristus itu mendapat eksplisitasi atau ungkapannya secara paling radikal melalui Gereja di dalam perayaan Ekaristi. Demikianlah Ekaristi menjadi sakramen pemberian diri Allah melalui Kristus secara paling radikal dan real dalam Gereja bagi dunia.

Dalam beberapa tulisan, Rahner juga menegaskan ajaran tradisional Gereja mengenai realis praesentia dan legitimasi devosi Ekaristi. ${ }^{31}$ Dalam hal realis praesentia, Rahner berpangkal dari ajaran Konsili Trento, yang dengan jelas mengajarkan kehadiran real atau nyata dari Kristus di dalam Ekaristi, yakni dalam rupa roti dan anggur. ${ }^{32}$ Kehadiran real Kristus dalam Ekaristi itu tidak boleh dipisahkan dari kehadiran kurban salibNya, yang terjadi sekali untuk selamanya. Kehadiran kurban Kristus yang

30 Karl Rahner, Grundkurs des Glaubens, S. 410.

31 Misalnya, "The Presence of Christ in the Sacrament of the Lord's Supper," Theological Investigations, Volume IV, pp. 287-311; "The Duration of the Presence of Christ after Communion," Theological Investigations, Volume IV, pp. 312-320; "The Presence of the Lord in the Christian Community at Worship," Theological Investigations, Volume X, pp. 71-83.

32 Rahner menunjuk, misalnya, ajaran Konsili Trento itu seperti disampaikan dalam Denzinger 874/DS 1636-1637. Lih. "The Presence of Christ in the Sacrament of the Lord's Supper," pp. 291-292. 
real dalam Ekaristi terus berlangsung dan bertahan sesudah komuni dan karena itulah umat beriman sangat wajar bila masih melakukan sembah sujud atau melakukan adorasi kepada Sakramen Maha-kudus. Dengan menekankan kesatuan realis praesentia Christi dengan kurban salib-Nya, Rahner menunjukkan keterbatasan teologi Skolastik dan juga cara Konsili Trento membahas tema Ekaristi, yaitu ketika pembicaraan tentang Ekaristi dipisahkan melalui pembagian tema tentang realis praesentia, kurban, dan sakramen. ${ }^{33}$

\section{EKARISTI SEBAGAI SAKRAMEN KEHIDUPAN SEHARI-HARI}

Kini perlu dibahas secara khusus hubungan Ekaristi dengan kehidupan sehari-hari dalam alur pemikiran teologis Rahner. Di satu pihak, tulisan ini dipermudah oleh artikel Rahner sendiri yang membahas Ekaristi dan hubungannya dengan kehidupan sehari-hari. ${ }^{34}$ Namun, di lain pihak, penulis berpendapat bahwa kekayaan kedalaman teologi Rahner mengenai hubungan Ekaristi dengan hidup sehari-hari tidak terbatas pada satu artikel Rahner itu saja tetapi juga terdapat dalam seluruh teologinya, khususnya teologi sakramentalnya. Bahkan dapat dikatakan bahwa artikel Rahner mengenai hubungan Ekaristi dengan hidup sehari-hari tersebut dapat lebih mudah dipahami dan dimengerti jika ditempatkan dalam keseluruhan teologinya.

Pembahasan Rahner tentang hubungan Ekaristi dengan hidup sehari-hari dimulai dengan catatan kritis Rahner mengenai arti hidup sehari-hari dalam pandangan populer. Tampak memang bahwa perhatian pastoral Rahner sangatlah menonjol dalam tulisan teologisnya termasuk tentang Ekaristi ini. ${ }^{35}$ Pada umumnya orang menganut dualisme tentang hidup sehari-hari yang bersifat profan dan hidup peribadatan dengan Allah yang bersifat kudus. Yang kudus dan yang profan

33 "The Presence of Christ in the Sacrament of the Lord's Supper," p. 309.

34 Karl Rahner, "The Eucharist and Our Daily Lives," lihat catatan kaki no. 7 pada tulisan kami ini di atas.

35 Hal ini disinggung oleh Wai Shu Chan, "Karl Rahner's Thought on Sacrament," http:/ / www.docjax.com/document/view.shtml?id=824472\&title=\%E2\%80\%9CKarl\%20Rahner\&. Diunduh tanggal 11 Agustus 2013. 
dipandang sebagai dua dunia yang terpisah dan berbeda. Begitulah misalnya Rahner menyatakan: "Saat kita meninggalkan lingkungan suci kita masuk ke lingkungan sehari-hari, yaitu dunia yang sepenuhnya profan, dan di dalam dunia ini Allah terasa jauh." ${ }^{\prime 36}$ Dengan cara pandang yang memisahkan yang kudus dan yang profan itu orang menghayati acara dan kesibukan sehari-hari sebagai kegiatan profan yang tanpa Allah. Di sini jelas bahwa Rahner merenungkan cara hidup manusia modern yang sekularistik. Dalam masyarakat yang menganut sekularisme, terjadi pemisahan antara agama dan kehidupan sosial-politis masyarakat. Dalam arus pemikiran yang sekularistik ini, kehidupan iman dan hubungannya dengan Allah dipandang terpisah dari kehidupan dan kegiatan sehari-hari dalam masyarakat.

Rahner menolak cara pandang dikotomis atau yang memisahkan antara yang sakral dan yang profan di atas. Untuk menjelaskan hal ini Rahner menyatakan inti tesisnya: "Ekaristi sebagai sakramen perjumpaan abadi dengan Allah, yang menjadi puncak sejarah keselamatan kita dalam sejarah hidup kita pribadi adalah sakramen hidup sehari- hari." ${ }^{37}$ Ekaristi adalah sakramen kehidupan sehari-hari. Itulah inti tesis Rahner tentang hubungan Ekaristi dan kehidupan sehari-hari. Bagai- mana gagasan ini dijelaskan oleh Rahner? Atas dasar seluruh alur teologi Rahner, penulis membahasnya dalam tiga langkah.

Langkah pertama, kita mesti konsisten memahami teologi Rahner dari kata kuncinya mengenai rahmat sebagai pemberian diri Allah (Selbstmitteilung Gottes). Pemberian diri Allah terjadi dan berlangsung di mana-mana dan menopang seluruh dunia dan umat manusia. ${ }^{38}$ Dengan demikian bagi Rahner tidak ada dunia dan seluruh masyarakat manusianya yang terlepas dalam relasinya dengan Allah, sebab Allah selalu hadir dan memberikan diri-Nya kepada dunia dan umat manusia. Seluruh sejarah umat manusia menjadi sejarah keselamatan Allah justru

36 Karl Rahner, “The Eucharist and Our Daily Lives," p. 212.

37 Karl Rahner, "The Eucharist and Our Daily Lives," p. 216.

38 Bdk. Karl Rahner, Über die Sakramente der Kirche, SS. 13-14. 
karena sejarah manusia ini menjadi medan pemberian diri Allah. Dalam pengertian inilah paham dualisme mengenai pemisahan antara hidup dengan Allah dan hidup sehari-hari ditolak oleh Rahner. Bagi Rahner, kehidupan sehari-hari selalu ditopang dan dimungkinkan oleh pemberian diri Allah, atau dirumuskan terbalik: pemberian diri Allah itu juga yang menjadi kehidupan sehari-hari kita. Kehidupan manusia se- lalu ada bersama dengan Allah, sebab Allah selalu hadir dan memberikan diriNya kepada seluruh dimensi kehidupan manusia; sekaligus yang sebaliknya harus dikatakan: seluruh segi kehidupan manusia ini mungkin dan dapat berlangsung justru karena mengalami pemberian diri Allah. Seperti sudah disebutkan di atas, pemberian diri Allah ini bagi Rahner tidak bergantung pada kesadaran manusia akan kehadiran Allah yang memberikan diri itu. Entah manusia mengakui atau tidak, entah manusia menyadari atau tidak, Allah tetap memberikan diri-Nya kepada dunia dan umat manusia sepanjang sejarahnya. Sekali lagi, pemahaman Rahner tentang hal ini jelas mudah dimengerti dalam kerangka pemikiran sakramentalnya.

Langkah kedua, dengan memahami Ekaristi sebagai perayaan kehadiran pemberian diri Kristus secara paling radikal dan real, diri dan hidup Yesus Kristus menjadi hidup kita sehari-hari. Persoalannya ialah bagaimana hidup Kristus itu dapat menjadi hidup kita sehari-hari. Kita dapat bertolak dari pandangan populer umat mengenai rahmat yang dimohon dalam perayaan Ekaristi. Orang pada umumnya membayangkan bahwa dengan perayaan Ekaristi mereka memperoleh kekuatan sebagai rahmat Allah sehingga mereka menjadi kuat dan bertahan dalam perjuangan hidup sehari-hari. Kita amat mudah menemukan isi doa- doa permohonan dalam perayaan Ekaristi. Pada umumnya orang me- mohon agar Allah menganugerahkan kepadanya rahmat kekuatan, ke- sehatan, kebijaksanaan, kehendak yang kuat, daya tahan, dan seterus- nya. Dengan rahmat Allah yang dimohon dalam Ekaristi ini, orang ber- iman menjadi yakin dapat melanjutkan perjuangan hidup sehari-hari dengan segala suka dan dukanya. Rahner menunjukkan bahwa cara pemahaman seperti ini melihat rahmat seolah-olah sebagai sesuatu yang 
dimasukkan ke dalam diri umat beriman. Rahmat, sebagai pemberian diri Allah, dipandang sebagai sesuatu yang seolah-olah belum terjadi dan belum hadir dalam hidup manusia dan dunia. Berdasarkan pemikiran langkah pertama, jelaslah bahwa cara pandang ini tidak menjadi pilihan Rahner.

Rahner menyatakan:

Dalam perayaan Ekaristi kita menerima setiap hari kehidupan seharihari Yesus Kristus sendiri, yakni kehidupan Kristus yang mencakup seluruh hidup-Nya termasuk wafat-Nya. Dan kehidupan sehari-hari yang diterima dari Allah itu adalah kehidupan Kristus sendiri yang dianugerahkan bersama dengan daya kekuatan dan kekudusan-Nya, serta dengan rahmat-Nya, untuk menghayati hidup sehari-hari. ${ }^{39}$

Dalam perayaan Ekaristi, pemberian diri Allah melalui Kristus dengan seluruh pribadi dan karya-Nya, belas kasih dan pengampunanNya, daya tahan dan kekuatan-Nya dianugerahkan kepada kita. Dengan merayakan Ekaristi kita tidak menerima kekuatan dan rahmat Allah seolah-olah hal itu berasal dari luar dan dimasukkan ke dalam diri kita, tetapi hidup Allah yang puncaknya diberikan atau dianugerahkan melalui Kristus kepada Gereja dinyatakan atau ditampakkan; atau menurut rumusan sakramen: ditandakan dan sekaligus dihadirkan atau dilaksanakan, dalam bentuknya yang paling real dan radikal. Hidup Allah yang diberikan itu adalah hidup Yesus Kristus, Sang Sabda yang telah menjadi manusia, yaitu kehidupan Allah yang telah ada dan masuk serta menebus hidup dan sejarah umat manusia. Dalam Ekaristi hidup Allah melalui Kristus yang demikianlah yang menjadi hidup sehari-hari kita. Dengan kata lain, bagi Rahner "Ekaristi pertama-tama dan terutama ialah tindakan suci yang dilaksanakan oleh Allah sendiri atas diri kita dan kini dilimpahkan kepada kita sebagai kehidupan kita seharihari." ${ }^{40}$ Berkat Ekaristi, kehidupan sehari-hari kita tidak lain adalah kehidupan sehari-hari Kristus yang diamanatkan kepada kita untuk kita

39 Karl Rahner, "The Eucharist and Our Daily Lives," p. 220.

40 Karl Rahner, “The Eucharist and Our Daily Lives," pp. 119-220. 
wujudkan dan jabarkan dalam suka-duka perjuangan hidup kita seharihari.

Kedalaman makna Ekaristi bagi hidup sehari-hari juga digali Rahner dari makna komuni suci. Komuni suci adalah saat kita menerima tubuh dan/atau darah Kristus. Dengan komuni itu kita dipersatukan dengan Kristus secara istimewa dan radikal, karena dengan menerima tubuh dan darah Kristus dalam rupa roti dan anggur itu orang benar-benar dipersatukan sebagai sebuah kesadaran dengan seluruh hidup Kristus dengan segala keutuhan dan kehidupan sehari-hari-Nya. Persatuan dengan Allah yang terjadi karena pemberian diri Allah yang ditanggapi secara sempurna melalui Kristus dihadirkan atau dianugerahkan kepada kita saat komuni. Sekali lagi bukan suatu anugerah yang seolah-olah baru masuk dari luar ke dalam diri kita tetapi sebagai rahmat atau pemberian diri Allah yang sudah ada dan dianugerahkan tetapi kini dinyatakan dalam bentuknya yang paling real dan radikal yakni melalui perayaan Ekaristi. Bila di atas dikatakan bahwa hidup sehari-hari kita tidak lain adalah hidup sehari-hari Kristus yang diwujudkan, maka hidup sehari-hari menjadi perpanjangan dan penerusan dari komuni suci itu. Rahner berkata: “Hidup sehari-hari adalah perpanjangan dan bertumbuhnya komuni di dalam realitas hidup yang kelabu, dan karenanya kehidupan kita sehari-hari yang biasa dan sederhana kembali men-jadi persiapan atas komuni itu lagi." ${ }^{11}$ Komuni yang dimaksudkan Rahner di sini adalah komuni dalam pengertian sebagai bagian dari liturgi Ekaristi, saat kita dipersatukan dengan hidup Kristus yang mencakup seluruh peristiwa penyelamatan-Nya, dengan wafat dan kebangkitan-Nya tetapi juga dengan segala kehidupan sehari-hari-Nya yang dianugerahkan kepada kita. Persatuan dengan hidup Kristus inilah yang diperpanjang dan dilanjutkan dalam kehidupan sehari-hari kita dengan segala suka dan duka perjuangan hidup ini. 
Langkah ketiga, Ekaristi sebagai sakramen sehari-hari berimplikasi pada komitmen untuk menghayati hidup Kristus dalam perjuangan suka dan duka, terang dan gelapnya kehidupan sehari-hari. Rahner berkata:

Menerapkan makna Ekaristi sebagai sakramen sehari-hari berarti kita sungguh-sungguh memiliki komitmen pada diri sendiri untuk melaksanakan, mengalami, menghidupi, dan menderita bagi kebenaran iman ini sehingga kebenaran itu tidak hanya melulu pada tingkatan teologis dan konseptual tetapi juga menjadi suatu kebenaran sebagai pengalaman batin kita. ${ }^{42}$

Untuk dapat menghayati kebenaran iman ini Rahner mengusulkan dua hal sebagai latihan. ${ }^{43}$ Pertama, orang "menarik diri" (withdraw into ourselves) dalam arti menemukan keheningan, seperti melakukan rekoleksi atau retret. Dalam latihan rohani ini yang penting adalah orang menyadari benar kehadiran penyertaan dan pemberian diri Allah melalui Kristus dalam hidupnya. Dengan terus mengumpulkan pengalaman kasih Allah yang telah memberikan diri-Nya itu orang berlatih masuk kepada kedalaman hatinya. Kedua, setelah menemukan keyakinan akan kasih Allah itu orang selalu berupaya untuk bertahan dalam pengertian tahan uji, tahan banting dalam menghadapi suka dan duka, terlebih kesulitan dan tantangan hidup sehari-hari. Rahner melihat kehidupan sehari-hari sebagai kehidupan apa adanya. Apa yang kita alami dalam kehidupan sehari-hari itu kini dihadapi dan dihayati sebagai penjabaran dan perwujudan kehidupan Kristus yang telah dianugerahan kepada kita melalui Ekaristi. Kehidupan sehari-hari yang kita hadapi setelah perayaan Ekaristi tidaklah berubah, tetapi kehidupan sehari-hari itu kini menjadi perpanjangan atau penerusan hidup Kristus yang kita terima dalam Ekaristi menurut konteks dan situasi konkret sehari-hari dengan segala tantangan dan masalahnya.

Bila Rahner menyebut pentingnya orang menarik diri dalam rangka kembali ke pengalaman batinnya, penulis meyakini bahwa Rahner tentu

42 Karl Rahner, "The Eucharist and Our Daily Lives," p. 221.

43 Karl Rahner, "The Eucharist and Our Daily Lives," pp. 221-222. 
juga memasukkan devosi Ekaristi sebagai bentuk ungkapannya yang konkret. Dalam tulisannya, "Eucharistic Worship," tiga tahun sebelum wafatnya, ${ }^{44}$ Rahner menyayangkan mundurnya praktik devosi Ekaristi dalam hidup Gereja pada beberapa dekade setelah Konsili Vatikan II:

Apabila kita mau jujur melihat kehidupan Gereja sekarang ini, kita tidak dapat menyangkal bahwa devosi Ekaristi telah mengalami penurunan atau kemunduran. Apakah Adorasi di hadapan tabernakel, dengan lampu kudusnya yang menyala, masih dipraktikkan sekarang ini seperti di masa lampau. ${ }^{45}$

Rahner menunjuk salah satu pandangan yang sering membuat praktik Adorasi Ekaristi di hadapan Sakramen Mahakudus menjadi berkurang, yakni adanya keyakinan bahwa kita dapat menyembah Allah di mana-mana dalam Roh dan kebenaran. Hal itu betul, kata Rahner, tetapi ia juga menyatakan bahwa praktik Adorasi Ekaristi di hadapan Sakramen Mahakudus sama sekali tidak perlu diperlawankan dengan keyakinan bahwa Allah ada di manapun dan kita dapat menyembahNya di manapun dalam Roh dan kebenaran. Bahkan Rahner berkata:

Tetapi kita juga harus jujur, kita bahkan harus mengakui bahwa hanya orang yang selalu dan di manapun bersatu dengan Allah dalam kasih akan sungguh-sungguh menghargai nilai liturgi, doa resmi dalam Gereja bersama saudara-saudarinya, dan juga menghargai ungkapan eksplisit dan badaniah (dengan tata gerak badan) untuk kedekatannya dengan Allah. Mereka yang ingin disatukan dengan Allah akan menghargai wujud atau bentuk eksplisit dan badaniah dari kesalehannya sebagai yang bernilai tinggi dari kesatuannya dengan Allah, yang dilakukannya dengan penuh cinta. ${ }^{46}$

Memang Tuhan hadir di mana-mana, dengan penuh cinta mendampingi dan menyertai perjalanan hidup kita sehari-hari, apalagi dengan

44 Karl Rahner, "Eucharistic Worship," Theological Investigations, Volume XXIII, pp. 113116. Dalam buku kumpulan tulisan Rahner ini ditunjuk sumber artikel Rahner, yakni Geist und Leben 54 (1981): 188-191.

45 Karl Rahner, “Eucharistic Worship,” p. 114.

46 Karl Rahner, “Eucharistic Worship," pp. 114-115. 
hidup-Nya yang telah diberikan dan telah kita terima dalam perayaan Ekaristi, tetapi Rahner juga menyerukan agar kita, umat beriman, tetap sadar bahwa

Allah yang hadir di mana-mana dalam kuasa dan cinta-Nya telah menciptakan beberapa tempat dan kenyataan yang membantu dan memudahkan kita umat-Nya, yakni umat yang terpenjara oleh waktu dan ruang, untuk dapat menangkap atau merasakan kehadiran-Nya, mengingat kita ini tidak selalu merasa dekat dengan-Nya. ${ }^{47}$

Menurut pendapat penulis, kesimpulan Rahner sangatlah jelas: devosi Ekaristi seperti halnya Adorasi Ekaristi mesti tetap dilanjutkan dan digalakkan dalam sepanjang sejarah Gereja. Karl Rahner menutup tulisannya mengenai devosi Ekaristi ini dengan berkata: "Lampu abadi di gereja-gereja Katolik terus mengundang kita untuk hening berlamalama di hadapan Misteri Penebusan kita." 48

\section{PENUTUP}

Dalam bagian penutup ini, penulis akan memaparkan relevansi pandangan Rahner di atas bagi Gereja masa sekarang. Paus Benediktus XVI telah menetapkan tahun 2012-2013 sebagai Tahun Iman. Paus Fransiskus, yang menggantikannya, juga melanjutkan penetapan perayaan tersebut. Latar belakang penetapan Tahun Iman ini kiranya sudah diketahui oleh semua pihak ialah berkaitan dengan peringatan 50 tahun dibukanya sidang Konsili Vatikan II yang telah memperbarui Gereja pada zaman modern ini.

Menurut Massimo Faggioli, ada dua garis kelompok atau pandangan terhadap Konsili Vatikan II: apakah Konsili Vatikan II itu sebuah akhir atau kesimpulan dari pembaruan sebelumnya, ataukah sebuah awal dari pembaruan? ${ }^{49}$ Faggioli mengakui bahwa istilah yang digunakan

47 Karl Rahner, "Eucharistic Worship," p. 116.

48 Karl Rahner, "Eucharistic Worship," p. 116.

49 Massimo Faggioli, Vatican II: The Battle for Meaning (New York-Marwah, NJ: Paulist Press, 2012), p. 119. 
untuk menyebut Konsili Vatikan II sebagai “suatu awal dari pembaruan" berasal dari pidato Karl Rahner yang berjudul "Awal dari Sebuah Permulaan." ${ }^{50}$ Faggioli membuat sebuah penelitian yang menarik. Baginya, dokumen liturgi Sacrosanctum Concilium dapat menjadi kunci untuk memahami seluruh dokumen Konsili Vatikan II. ${ }^{51}$ Ia melihat bahwa tujuan pembaruan liturgi dari Konsili Vatikan II adalah penemuan kembali sentralitas Kitab Suci dan Ekaristi. Tetapi tujuan pembaruan liturgi tersebut sekaligus menjadi tunas yang mengembangkan seluruh eklesiologi Vatikan II sendiri, ${ }^{52}$ yang dapat disebut sebagai eklesiologi ekaristik. Eklesiologi ekaristik berpangkal tolak dari dasar-dasar iman Gereja akan kehadiran Yesus Kristus dalam Gereja-Nya dan situasi pastoral-sosialrohani umat beriman dewasa ini. Dari sinilah dapat ditegaskan relevansi pembicaraan teologi Ekaristi dalam hubungannya dengan kehidupan sehari-hari. Pembicaraan tentang Ekaristi dan kaitannya dengan hidup sehari-hari merupakan pembicaran mengenai diri dan hakikat Gereja sendiri, sebagaimana diyakini oleh para Bapa Konsili Vatikan II yang mengatakan bahwa liturgi, terutama kurban ilahi Ekaristi,

merupakan upaya yang sangat membantu kaum beriman untuk dengan penghayatan mengungkapkan misteri Kristus serta hakikat asli Gereja yang sejati, serta memperlihatkan itu kepada orang-orang lain, yakni bahwa Gereja bersifat sekaligus manusiawi dan ilahi, kelihatan namun penuh kenyataan yang tak kelihatan, penuh semangat dalam kegiatan namun meluangkan waktu juga untuk kontemplasi, hadir di dunia namun sebagai musafir." 53

Gagasan Rahner mengenai Ekaristi sebagai sakramen sehari-hari menjawab diskusi populis yang sering terjebak dalam dikotomi antara altar dan pasar. Keprihatinan orang-orang agar Gereja tidak hanya sibuk

50 Massimo Faggioli, Vatican II: The Battle for Meaning, p. 120. Yang dimaksud Faggioli ialah tulisan Karl Rahner, "The Abiding Significance of the Second Vatican Council," Theological Investigations, Volume XX, pp. 90-102.

51 Massimo Faggioli, "Sacrosanctum Concilium and the Meaning of Vatican II," Theological Studies 71 (June 2010): 437-452.

52 Massimo Faggioli, “Sacrosanctum Concilium and the Meaning of Vatican II," p. 4.

53 Sacrosanctum Concilium, art. 2. 
di seputar altar tetapi juga harus terlibat dalam kancah perjuangan masyarakat di pasar tentulah valid atau sah. Tetapi dikotomi atau pemisahan semacam itu dapat berbahaya, seolah-olah hidup doa dalam konteks pengungkapan iman untuk hubungan dekatnya dengan Tuhan, dan hidup karya dalam konteks keterlibatan hidup di tengah masyarakat merupakan dua hal yang harus dibedakan dan makanya seolah-olah harus dibuat seimbang atau diperhatikan semua.

Tulisan ini mau menunjukkan sumbangan Rahner yang mengatakan bahwa pemahaman tentang rahmat Allah sebagai pemberian diri Allah yang senantiasa dianugerahkan kepada umat manusia dan sejarahnya tidak memperkenankan pemisahan dikotomis semacam itu. Secara konseptual hal itu mungkin, tetapi sebagai realitas iman akan kehadiran Allah-yang selalu memberikan diri-Nya dalam seluruh hidup kita dengan segala dimensinya, termasuk dimensi sosial atau apa yang sering dipandang "profan" — harus dikatakan bahwa hidup kita dalam bentuk kegiatan apapun, entah berdoa atau bekerja, sedang di altar atau di pasar-selalu menjadi medan Allah yang sedang memberikan diri-Nya, yakni kasih, belaskasih, dan pengampunan-Nya sekaligus. Rahner menyebut bahwa seluruh sejarah hidup dunia dan manusia dengan segala dimensinya telah menjadi sejarah keselamatan Allah justru karena Allah senantiasa memberikan diri-Nya kepada dunia dan sejarah umat manusia. Entah pemberian diri Allah itu disadari atau tidak, diakui atau tidak oleh manusia, bagi Rahner, tidak mengubah realitas pemberian diri Allah (Selbstmitteilung Gottes).

Ekaristi sebagai sakramen sehari-hari, dalam pandangan Rahner, bukanlah saat kita menantikan kekuatan rahmat dari surga seolah-olah sebagai suatu energi yang membuat kita menjadi tahan uji dan siap melaksanakan perutusan hidup sehari-hari. Ekaristi sebagai sakramen sehari-hari berarti bahwa Ekaristi menjadi ungkapan dalam bentuknya yang paling istimewa, radikal dan real dari hidup Tuhan sendiri yang dinyatakan dan dianugerahkan kepada kita, sedemikian rupa sehingga hidup sehari-hari kita menjadi perwujudan dan perpanjangan dari hidup Kristus sendiri menurut bentuknya yang konkret melalui usaha 
dan perjuangan perwujudan iman kita sehari-hari di tengah tugas perutusan kita yang sarat dengan suka dan duka, kegembiraan dan sekaligus keprihatinan atau kekecewaan. Pemberian diri Allah melalui Kristus yang dihadirkan, dinyatakan secara istimewa, dalam Ekaristi menjadi isi dari kesatuan dan persatuan umat beriman dengan Kristus, dan itulah yang dilanjutkan dalam perutusan hidup kita sehari-hari.

\section{DAFTAR RUJUKAN}

Benediktus XVI. Sacramentum Caritatis: Anjuran Apostolik Pasca-Sinode, 22 Februari 2007, terj. Ernest Mariyanto. Jakarta: Komisi Liturgi KWI, 2007.

Dych, William V. "Karl Rahner's Theology of Eucharist." Philosophy $\mathcal{E}$ Theology 11/1 (1998): 125-146.

FABC Papers, No. 129: Living the Eucharist in Asia - IX FABC Plenary Assembly 10-16 August, 2009 in Pope Pius XII Catholic Center, Manila, Philippines. Hongkong: FABC, 2010.

Faggioli, Massimo. "Sacrosanctum Concilium and the Meaning of Vatican II." Theological Studies 71 (June 2010): 437-452.

2012.

Vatican II: The Battle for Meaning. New York: Paulist Press,

John Paul II. Apostolic Letter Mane Nobiscum Domine For the Year of the Eucharist October 2004-October 2005. Vatican City: Libreria Editrice Vaticana, 2004. Encyclical Letter Ecclesia de Eucharistia on the Eucharist in Its Relationship to the Church. Vatican City: Libreria Editrice Vaticana, 2003.

Kehl, Medard. Kirche als Intitution. Frankfurt a. M.: Josef Knech, 1976.

Martasudjita, E. "Pemikiran Sakramental Karl Rahner dan Aktualisasinya." Melintas 20 (Desember 2004-Maret 2005): 75-93.

Meyer zu Schlochtern, Josef. Sakrament Kirche: Wirken Gottes im Handel der Menschen. Freiburg: Herder, 1992.

Rahner, Karl. "The Abiding Significance of the Second Vatican Council." Theological Investigations, Volume XX. London: Darton, Longman \& Todd, 1981, pp. 90-102. 
. "The Duration of the Presence of Christ after Communion." Theological Investigations, Volume IV. London: Darton, Longman \& Todd, 1974, pp. 312-320.

. "Eucharistic Worship." Theological Investigations, Volume XXIII. London: Darton, Longman \& Todd, 1992, pp. 113-116. "The Eucharist and Our Daily Lives." Theological Investigations, Volume VII. London: Darton, Longman \& Todd, 1971, pp. 211226.

. Grundkurs des Glaubens: Einführung in den Begriff des Christentums. Freiburg: Herder, 1991.

. Kirche und Sakrament. Freiburg: Herder, 1960.

. "The Presence of Christ in the Sacrament of the Lord's Supper." Theological Investigations, Volume IV. London: Darton, Longman \& Todd, 1974, pp. 287-311.

" "The Presence of the Lord in the Christian Community at Worship." Theological Investigations, Volume X. London: Darton, Longman \& Todd, 1973, pp. 71-83.

"Selbsmitteilung Gottes." In Herders Theologisches

Taschenlexikon, Hrsg. Karl Rahner, Band 7. Freiburg: Herder, 19721973, SS. 35-38.

"Über die Eigenart des christlichen Gottesbegriffs." In Karl Rahner, Schriften zur Theologie XV. Zürich: Benziger, 1983, SS. 185194. 1991.

Wai, Shu Chan. "Karl Rahner's Thought on Sacrament." http://www. docjax.com/document/view.shtml?id=824472\&title=\%E2\%80\%9 CKarl\%20Rahner\&. Diunduh tanggal 11 Agustus 2013. 